Barbara Chojnacka*

ORCID: 0000-0002-5635-3126

Szczecin, Poland

\title{
The Loneliness and Isolation of the Parentified Child in the Family
}

\author{
Samotność i izolacja \\ dziecka parentyfikowanego $\mathrm{w}$ rodzinie
}

\begin{abstract}
Parentification is a phenomenon that occurs in family life, consisting of a reversal of the roles of the child and their parent or parents (Böszörményi-Nagy $\&$ Spark, 1973). It is understood as a functional and/or emotional change of roles in which the child subordinates their own needs in order to adapt to and take care of the instrumental or psychological needs of the parent. The presented research is embedded in the interpretive paradigm. The research material allows the author to distinguish specific stages of parentified childhood (proper childhood, transition phase, adult childhood), within which appear categories such as responsibility, involuntary heroism, self-containment and loneliness. With regard to the last two categories, the author wishes to construct the image of a lonely child experiencing the reversal of family roles. There is a peculiar paradox at work: the loneliness of the child within the family environment. There is a lonely struggle for the survival and proper functioning of the family, while keeping up the appearance of a normally functioning
\end{abstract}

* Dr. Barbara Chojnacka, Institute of Pedagogy, University of Szczecin, email: barbara. chojnacka@usz.edu.pl. 
family, maintaining family homeostasis, and meeting their own needs and those of their loved ones.

Keywords: parentification; isolation; loneliness; child in family.

Abstrakt: Parentyfikacja to zjawisko występujące w życiu rodzinnym, które polega na odwróceniu ról między dzieckiem a rodzicem/rodzicami (Böszörményi-Nagy i Spark, 1973). W realizowanych przez autorkę badaniach, osadzonych w paradygmacie interpretatywnym, parentyfikacja staje się głównym przedmiotem zainteresowania. Na podstawie zgromadzonego materiału badawczego autorka wyróżnia etapy dzieciństwa parentyfikowanego, a w ich ramach takie kategorie jak: odpowiedzialność, niedobrowolny heroizm, samoradzenie sobie i osamotnienie. W odniesieniu do dwóch ostatnich kategorii autorka konstruuje obraz osamotnionego dziecka doświadczającego odwrócenia ról w rodzinie. Na uwagę zasługuje fakt, że dochodzi tu do swoistego paradoksu - osamotnienia dziecka w rodzinie, środowisku mu najbliższym. Toczy ono samotną walkę o przetrwanie i właściwe funkcjonowanie rodziny, zachowanie pozorów normalności, utrzymywanie rodzinnej homeostazy, zaspokojenie potrzeb swoich i bliskich.

Słowa kluczowe: parentyfikacja; izolacja; samotność; dziecko w rodzinie.

\section{Introduction}

Early experiences in the family home bring significant and often unavoidable consequences in the later life of almost every human being. This is the result of the closeness, special bonds and specific intimate relationships occurring in the family, as well as the family roles and unique kinds of rights and obligations that bind the family members. In fact, family and family happiness are still the most important values that Poles cherish in their everyday lives.

Parentification is a phenomenon that disturbs the functioning of the family, and above all significantly violates children's educational and developmental processes. Transferring responsibility for the whole family onto children seems to be a socially acceptable form of violence against children. Parentification is putting them in difficult situations in which they try to face tasks and challenges that exceed their strength.

The article presents the picture of a lonely childhood resulting from the experience of parentification. Loneliness and solitude, presented from a bi- 
ographical perspective, are one of the most important aspects of the experience of parentification. The distinction between different approaches to the sense of being alone or being left alone, as experienced by the child, is reflected in the analysed narratives. The adopted research perspective enables an attempt to recognise this phenomenon in the lifelong context of the parentified people, and provides reflection upon the different aspects of such loneliness.

\section{The phenomenon of parentification}

Parentification is a phenomenon that occurs in family life, consisting of a reversal of roles between the child and their parent or parents (Böszörményi-Nagy \& Spark, 1973). It is understood as a change of roles in which the children demote their own needs in order to adapt to and take care of the instrumental or psychological needs of the parents (Schier, 2012).

Parentification occurs when the child takes on responsibility for the tasks, duties, safety and emotions of the family members (usually the parents), mostly in order to maintain the balance known also as homeostasis of the family. Salvador Minuchin (1974) states that by violating the boundaries between the parents and children, parentification leads to the disruption of family hierarchy and power. Thus, the child becomes part of the parental subsystem - Minuchin describes such a child as a parental child. This state, if long-lasting, causes a number of negative consequences; according to Louise Earley and Deila Cushway (2002), these include overloading the child with an excessive amount of tasks that are beyond their developmental abilities, or the child's inability to meet their own needs, as a result of satisfying the needs of their parents.

Functional parentification consists of using the child to carry out work related to housekeeping and the organisation of family life; they take over duties such as cooking, cleaning, washing, taking care of siblings and other family members, or even earning money. The emotional exchange of these roles involves placing the child in the role of a trustee, family judge, therapist, or even the mediator in the parental conflicts (Hooper, 2008). The reversal of family roles, often unconscious, seems to be a socially accepted phenomenon. Children become so-called 'small heroes', showing specific strength and courage, since they take responsibility for the family environment, supporting their parents and guardians. However, this kind of heroism is marked by exhausting efforts that exceed their strength, undertaken due 
to a sense of duty or loyalty. Such children feel that they need to 'save' the family system and preserve intrinsic family bonds. When facing numerous tasks, responsibilities and expectations, children undertaking them display strength, bravery, and also take responsibility for their family environment, and thus support their parents and guardians.

The reversal of the natural order of family roles indisputably affects the child's development. The assessment of this impact should include the following factors: the type of family boundaries, openness in defining the child's tasks, the nature of the child's work, the person whom the child is to look after, and the degree of internalisation of the guardians' needs. The relevance of the tasks performed and the kind of undertaken responsibilities should also be taken into account (Jurkovic, 1997). Nancy D. Chase (1999) distinguished healthy (adaptive) and pathological (destructive) parentification. The first involves 'situational or culturally conditioned, isolated child behaviours related to the care for parents/siblings, perceived as sporadic or normative' (Grzegorzewska, 2016); this can positively influence the child's development by shaping their conviction that they are competent and helpful to their parents, thus developing responsibility and a sense of agency. By contrast, destructive parentification occurs when the parent imposes a specific role upon the child as a result of their helplessness or impotence, while expecting behaviours typical of adults (Schier, 2015). In this case, the child is burdened with obligations significantly exceeding their abilities and strength; this has many negative consequences, usually identified only in the adult life of the parentified person.

The experience of parentification is a difficult one, and it is usually unconscious and undisclosed - it is hidden behind the closed door of the family home. It may seem that it is also an element of the 'natural order' of the family, resulting from its functioning as a system in which, in the absence of one family member's ability to perform the assigned tasks (roles), and in order to maintain its durability ('being together'), the other members (children) take over these tasks (de Barbaro, 1999).

\section{The research methodology}

The study has been conducted according to the interpretative paradigm (Sławecki, 2012) $)^{1}$, with the aim of recognising what parentification is, and

\footnotetext{
${ }^{1}$ The research for the author's doctoral dissertation, The experience of parentification
} 
what the experience of parentification in the family consists of. The experience of the family role-reversal appears as a phenomenon, mechanism, or set of behaviours happening in the course of human life; as such, it constitutes an element of the person's biography, shaping it in various ways. The subject of this research is the experience of parentification examined from a biographical perspective; this consists of respondents' biographical experiences that are related to the sphere of family life, and the meaning attributed to them by the parentified individuals.

The biographical perspective allows us to capture the subjective character of the research subject. As Danuta Lalak (2010) states, biographical research brings the social sciences into the context of social reality, in which the individuality of the actor must be taken into account, and this individuality is in turn structured and socially conditioned. The biography of a human being becomes a specific platform for the reflective integration of human activities, such as cognition, vigour, communication, and meeting others. This deepens self-awareness and the ability for biographical learning. In terms of science and cognition, biography is a subjective structure of the lived life.

The data collection technique mainly consists of Fritz Schütze's autobiographical narrative interview method (1983), which allows the researcher to get to know the individual's perception of the world, and the most intimate surroundings and experiences of the research participant. Interlocutors present their own past, i.e. the course of their life seen from their own point of view. Human beings are active subjects constantly interpreting their experiences and gained information; they negotiate the meaning of events and objects during their meeting with others (Urbaniak-Zając \& Kos, 2013). Thus, by using the biographical approach, the researcher studies the life of a particular individual as presented by him/herself in the narrative form.

During the research, the interlocutors were asked to tell the story of their life with particular reference to their family. The researcher was interested in how people who have experienced parentification - and who are now adults - present their experience from the time perspective, and how they situate this experience in their own biography.

In the attempt to answer the research questions concerning the meaning and sense given to family experiences, people who had experienced family role-reversal in their childhood were sought. The literature on the subject

form the biographical perspective, was conducted from April to September 2018. The defence of the dissertation took place on 9 July 2019. 
points to specific risk groups which have increased probability of parentification occurrence. Therefore, such risk groups were treated as criteria for the purposeful selection of interlocutors. Accordingly, the following selection criteria for the study were formulated: experience of addiction in the family, illness and/or disability of a parent or other family member, large families, mono-parent families, and transnational (disconnected) families.

The research group consisted of 25 people, aged 20-67 years, comprising 7 men and 19 women; they joined the research according to the snowball method, if they reported a specific fitness to the above-mentioned selection criteria. The empirical material obtained during the study was later transcribed and analysed in accordance with the guidelines constructed by Fritz Schütze (1983). These consist of the following stages: (1) formal analysis of the text (establishing a communication scheme; selecting narrative, argumentative and descriptive fragments; dividing the material into segments according to the terms of the taken subject; time to which these narratives relate; the type of speech or intonation), (2) structural description (subjecting each segment to detailed analysis); constitution of so-called cognitive figures - selection of biographical advisors, orienting others, i.e. people setting the course of the biography, significant ones (Schütze, 1983); (3) constructing theoretical structures (background construction, screening, theoretical commentary, argumentative commentary, coda), process structures (biographical schemes of activity, institutional patterns, trajectories, metamorphoses), and analytic abstraction (generalisation, i.e. appointing common categories to all the stories obtained from interviews); and (4) contrasting comparison, and building the theoretical model. The application of F. Schütze's analytical procedure allowed the selection of specific problem areas related to the experience of parentification, which enabled its full picture to be presented in the doctoral dissertation.

\section{The results}

The biographical perspective adopted in the presented research allows the problem of parentification to be understood as an individual experience emerging from specific family and non-family circumstances. The reversal of family roles had marked the course of the individuals' life, although it had not often been the main problem in a given family. Childhood, being a key stage in human life, in their case had been marked in a specific way, which will be referred to as parentified childhood. Based on the analysis of col- 
lected research material, the phases of parentified childhood and its aspects and characteristics were distinguished. The narrators clearly indicated that a feeling of loneliness and solitude accompanied their experience of parentification. This is very important for learning and trying to understand the mechanisms of family role-reversal.

On the basis of the narratives of the parentified individuals, three stages of childhood were distinguished. These can be seen as a kind of mirror image of the course of family role-reversal: proper childhood, transition phase, and adult childhood.

Diagram 1. Phases of parentified childhood. ${ }^{2}$

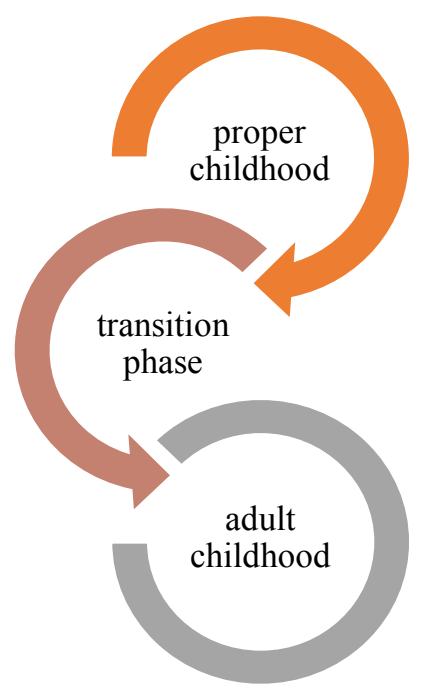

Source: Own study.

The picture of proper childhood which emerges from the narratives of the interlocutors is that they perceive it as the time of proper, or relatively correct functioning of the family - as a period of normality, when the family

2 The stages of parentified childhood are presented in a more extensive manner in the doctoral dissertation The experience of parentification form the biographical perspective (2019). 
roles seem natural (this is carefree childhood, during which the parents take care of the child). The interlocutors pointed out that as young children, they were unable to notice, understand or comprehend the proper functioning of the family environment, and they would not have recognised any problems (that in many cases had already been occurring). Such things would stay outside the child's consciousness and exceed their ability to see or understand them.

On the other hand, such a narrative construction regarding childhood may be a way of building a safe point of reference to the past, allowing the adult to explain the more difficult parts of childhood and to confirm the belief that 'it has not always been this way'. Interlocutors considered this part of their childhood as a distant memory, perceived as images, feelings or events:

My memories from the age of four, five and six, appear as images in my head. I remember these things very well, because I remember that my family was full then: there was dad, there was mother and everything was fine. I did not notice any things that would negatively affect the image of the family. (W4, woman, 37 years old)

However, the next stage, referred to as the transition phase, changes this perspective. It includes circumstances and events significant or contributing to the transition from proper childhood to adult childhood. This transitional phase is accompanied by situations in which the child confronts the family problems. It often involves the child taking the initiative and undertaking actions that emotionally and instrumentally exceed their capabilities and strength.

The child gradually or rapidly enters the stage of adult childhood, understood here as 'non-childhood' - i.e. childhood that has been lost or even taken away. The interlocutors clearly described this period as a time of hardships, duties, loneliness, attempts at raising themselves and siblings, etc. On the basis of the obtained narratives, the following elements of adult childhood were distinguished: responsibility, involuntary heroism, self-managing, and loneliness.

The listed aspects of adult childhood determine the specificity of the experience of parentification as a process with signs of increasing trauma, or involvement in situations and responsibilities that exceed the child's strength. 
Diagram 2. Elements/aspects of adult childhood.

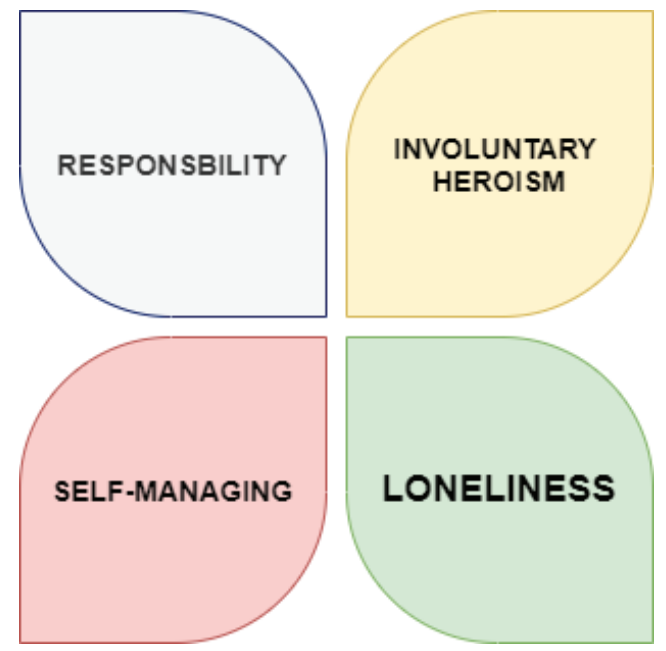

Source: Own study.

The responsibility of the parentified individuals was seen particularly in the fact that the child provided support for other family members (parents or siblings), took over their obligations and comforted them - in a way that forced them to feel it was necessary to take care of the proper functioning of the family, in an instrumental and emotional sense. Instrumental tasks included activities such as almost full-time housekeeping (washing, tidying up, window cleaning, shopping, cooking), taking care of younger siblings, attending parents' meetings at school, and even financially supporting the family. On the other hand, emotional or moral responsibility meant caring for parents or other family members (mainly siblings).

I took care of her all the time. I fed her. I even took her to kindergarten or escorted her to other places. All the time there was a thought in my head, that I have to look after her. Not that I must, you see, this was never 'I must'. It was not even compulsory for someone to tell me to do something, I just felt that I have a mission, you know. Such missions are so strange. And concern so many things. I taught her so many things, I taught her how to read, I taught her to write. (W7, woman, 29 years old) 
Thus the child had been taking in her frail arms the burden of family problems and obligations. The parents, on the other hand, allowed the child this kind of involvement, and sometimes even enforced it or defined it as one of the principles - or norms - of family life.

My mother realised that I could make money, since the moment when I took my first odd job as a 14-year-old girl, still attending high school. And my mother, seeing me bring some money home, told me openly: 'If you earn money already, then from now on I will only keep your younger brother, and you will just have to support yourself'. So, as a 14-year-old I was left alone, having to learn, work and take care of myself. (W8, woman, 35 years old)

The quoted fragment points out another essential element of the image of adult childhood, namely obligatory 'self-managing' by the child and the loneliness that is related to it.

'Self-managing' means taking up an independent attitude in most spheres of one's own life and family life. The child would have to cope with their own problems and needs, try to meet their needs on their own, and face the troubles and challenges alone. This concerns functioning at school, among peers, and in the family environment. In each of these environments, 'self-managing children' become brave children, who are coping, capable and fit to deal with everyday difficulties. The parentified children adapt to the reality and demands placed upon them. At the same time, such 'self-managing' children would seem to be torn between their own feelings (suffering, inner pain, a sense of inadequacy), and the deeds and actions that they had to undertake. By becoming part of the parental subsystems, as Salvador Minuchin notes (1974), such children assume responsibility for the family and family members.

In a sense, the family problems that the parentified children confronted forced them to take up this lonely fight of self-managing. Such situationally enforced independence resulted in the children having to present themselves as more mature than they really were. This attitude became their strategy for life, yet it was not fully internalised. As one of the respondents said, it was a kind of superficial reconciliation with what one experiences - acceptance and sole fulfilment of the given role.

At first glance you could say that I came to terms with the fact that I had no support from my family nor anybody else, and I had to deal with everything alone. (W8, woman, 35 years old) 
In addition to being burdened with numerous tasks, the children are left alone to deal with their own development and meeting their needs. Paradoxically, the parentified children experience loneliness even though they function within the family - which should be their closest environment. Such adult children battle with the lonely struggle for survival and proper functioning of the family, keeping up appearances of normality, safeguarding the family secrets regarding these difficulties and problems, and satisfying their own and the family members' needs. In such conditions, loneliness becomes hidden, internal and unnoticed by others.

Jadwiga Izdebska (2004) writes about the loneliness of the child in the family, emphasising the dramatic character of this situation. The child bears no fault nor chooses this situation, and yet is left to fend for themselves, with the feeling of fear and uncertainty. As Maria Łopatkowa (1983) states, intense loneliness may be damaging for the adult psyche, but it always damages the child. For adults, loneliness is sometimes a choice - but not a necessity. For the child, loneliness is never a choice, since it is contrary to the nature of the childhood period. M. Łopatkowa (1983) distinguishes the following characteristics and elements of the loneliness of the parentified child:

- loneliness is always an individual experience, subjectively perceived by the child;

- it is associated with strong stress and is dangerous to the child's functioning, development or education - it can be a disruptive factor;

- it is the result of external circumstances - irregularities in the relationship between the child and their relatives, or disorders in the functioning of the family.

The above-mentioned features reflect the loneliness of the parentified child. By interpreting the narratives obtained in this study, more specific aspects of such loneliness can be detailed:

- negligence of parental duties, forcing the children to take care of themselves and take care of (usually younger) siblings;

- lack of emotional closeness with the parental figures - the respondents emphasised that their parents did not show them love. In one of the interviews the following words appeared: 'I cannot say that my parents raised me, they simply kept me' (W10, woman, 35 years old);

- lack of experiencing childhood as a calm, carefree period during which the child is a subject of education and care. Instead, the child receives tasks, duties, requirements and expectations, the implementation of which is not always welcomed by parents; 
- lacking or limited contact with other children, which denies them the chance to play, find friends or establish friendships - it is, in fact, a kind of social isolation of a child.

There were many children, so, of course, I was pushed to take care of the buggies. And there were all kind of tasks while running around the building with these buggies, watching over the kids. And when my friends could still stay outside, I had to help my mother to bathe the kids, help my mother to clean up. (W11, woman, 45 years old)

- lack of real outside support - neither the family nor the social services react to the situation of the lonely parentified child. The interviewees emphasised the importance of other family members helping them in so-called survival by showing support, spending time together, talking, etc. None of the obtained narratives mentions that family members aimed to change the existing situation, by improving it or providing the child with proper conditions for development. As an example, I would like to present the situation in which a grandmother, described by one of the respondents as a significant person, passively observed how her 12-year-old granddaughter dealt with the household and her brothers' upbringing during their parents' long absence (caused by taking a job far away from home): 'Grandma was simply there up to the moment when I turned 18 . She just sat there, so nobody would find any fault with the fact that I'm not an adult' (W10, woman, 35 years old).

None of the interlocutors indicated any attempts of intervention by other family members.

The situation is similar when the possible institutional support is taken into account. It was revealed that the only institution present in the lives and narratives of the respondents was school. However, it was presented in a definitely negative light: not as supportive, showing understanding and helpfulness; but rather, as avoiding deeper knowledge, and belittling the children's problems. 'I have had many conversations with my teachers. They kept saying that if I had to work, I should go to the part-time or evening high school. Nobody seemed to understand this' (W8, woman, 35 years old).

Therefore, the parentified child appears to be a lonely/alone/isolated hero - an involuntary hero - forced into heroism directly (by orders, as well as duties and statements assigned) or indirectly (as a result of circumstances, their own sense of responsibility for the family, feeling bonds and duty to- 
wards family and family members, especially parents). It is no accident that such a sense of responsibility has been identified as the main element of the experience of parentification, since it can also trigger further mechanisms related to this phenomenon.

\section{Loneliness and isolation of the parentified individuals}

Although special attention has been paid to loneliness as one of the categories describing the experience of parentification, one should also ask the question of whether being parentified becomes a source of feeling lonely and isolated, thus broadening the interpretative framework of the phenomenon. The focus was previously on situations in which children had to demonstrate self-independence, self-managing, self-action; this prefix 'self' indicates acting or functioning by one's own efforts. Therefore, while analysing the narratives of people who have experienced the family role-reversal, it should be noted that some of the cited aspects of loneliness could be interpreted as manifestations of loneliness and isolation felt by children in the context of their individual experiences.

This kind of being 'alone', which is related to everyday situations, duties, and to important milestone events, is also considered as 'being alone'; this could refer to the contemporary philosophy of loneliness, which emphasises the importance of the ability to be alone with oneself. This is an ability that prompts reflection on the meaning of one's own life and life in general, induces thinking about last things, and potentially gives the opportunity to enjoy one's own existence (Dubas, 2006). In this research, this kind of loneliness is reflected in the form of interlocutors dealing with their own experiences, family problems, and their consequences for the parentified children. It is reflected in individual strategies, thanks to which the narrators performed some kind of self-diagnosis, confronted their own suffering, named the specific problems, and usually sought for a solution or help. ${ }^{3}$ Such situations of 'being with oneself' were involuntary, and in fact unfavourable, since they resulted from the disturbed functioning of the family. However, these created conditions for reflection, which is essential in relation to the actions taken to save oneself. It can be considered as a positive dimension

3 These processes were more extensively described in the aforementioned doctoral dissertation. 
of parentification, because it resulted in the parentified people finding the strength to work on trajectories (Riemann \& Schütze, 1992).

Another indication or consequence of the parentification experience was the social isolation of the interlocutors when they were children. A child who is committed to 'family matters', becoming more absorbed in and responsible for the family and its members, becomes its prisoner. Such a child lacks the time and opportunities to establish and develop social contacts, by meeting or playing with other children.

I remember that a friend came once, asking if we could go for a walk ... I was afraid to ask if I could leave. She could not understand it: 'But how's that possible that you cannot go out? Can't you go out after school, in the afternoon?' So I tell her this: 'No, I have to ask first if I can go, if I can find time, if my mother has no other duties.' Anyway, sometimes ... I also stayed with the younger siblings, so there wasn't such an option at all. Of course, I had plans, especially in the spring and summer, the most beautiful period, when one could play in the yard. (W11, woman, 45 years old)

The above quoted passage draws our attention to the obligations resting upon the shoulders of the parentified children, limiting (and in some cases even preventing) contact with other children. Psychology treats these kinds of social relations as crucial for the child's development; they are especially important for shaping prosocial and altruistic behaviours, as well as cooperative and communicative skills (Eiseberg, 1992). The interlocutors emphasised that their group of friends was either very narrow (one or two friends/ colleagues) or they had no friends at all. In the first case, faithful friends provided significant support in their survival and attempts at overcoming difficulties. In the second situation, the parentified people again had to face problems or work on their trajectory alone. One of the important stages consists of abandoning this attitude of self-reliance and self-managing, realising that one should seek help outside the family.

As for the rest of these experiences, they are with me to this day. They are not only positive - that I am resourceful, and so on. They certainly are, but not all are positive. There are also negative sides. I'm going to undergo therapy, because I already feel that I can't handle this alone. (W8, woman, 35 years old)

The above passage also indicates the consequences of parentification, both positive and negative ones. Positive effects include a sense of agency 
and being helpful, getting admiration and respect from others, resourcefulness, organisational skills, decision-making ability, responsibility, and competence at pursuing goals. However, the consequences described as negative are much more severe. They generate a number of problems, difficulties, failures or suffering in the lives of the parentified people and also their relatives. Undoubtedly, among them we can find loneliness, solitude and isolation. They are accompanied by: failure to meet the emotional needs of the child; overloading the child with duties; effecting a sense of enslavement; bringing about a destructive sense of responsibility; disordered and difficult relations with the generational family (parents, siblings); problems in relationships with members of their own reproductive family (spouse/partner, children); and psychosomatic ailments (depression, workaholism, unidentified body aches and tensions, illnesses). Most of these consequences appear as individual problems that the parentified people had to face in their childhood or adulthood. Their struggle with family experiences often meant leaving the house - both mentally and physically - and that can also be considered as 'quitting the state of loneliness' and reaching out to others, to the outside world - in search of help, in search of their own self and their own path in life.

\section{Summary}

The interlocutors' construction of narratives about their childhood is a kind of process of reproducing and interpreting events and experiences by talking about them or being silent; justifying parents or themselves; describing, arguing, and placing the experience of parentification in the history of their life.

A childhood during which the child faces the necessity of the so-called fight for survival (their own or their family's) is a childhood lost. Such events trigger mechanisms that shift attention to meeting not only one's own needs, but those of the family and family members as well. The respondents clearly pointed to the fact that for them this was a period of hardships, duties, loneliness, attempts to raise themselves and their siblings, etc. Therefore, the parentified children, instead of receiving love, care, protection and interest, must give these to their family members, and have to push their own needs to the background, or fulfil their own needs themselves.

All the various aspects of the parentified child's self-independence indicated in this article, such as self-managing, loneliness, solitude and isolation, 
indicate that the nature of their experiences and the phenomenon of parentification are very complex.

\section{References}

Barbaro de, B. (1999). Wprowadzenie do systemowego rozumienia rodziny. Kraków: Wydawnictwo Uniwersytetu Jagiellońskiego.

Böszörményi-Nagy, I. \& Spark, G. (1973). Invisible Loyalties: Reciprocity in Intergenerational Family Therapy. New York: Harper and Row.

Chase, N. D. (1999). Parentification: An Overview of Therapy, Research and Societal Issues. In N. D. Chase (ed.), Burdened Children Theory. Research and Treatment of Parentification (pp. 3-34). Thousand Oaks, London. New Delhi: Sage Publications.

Dubas, E. (2006). Samotność - uniwersalny „temat” życia ludzkiego i wychowania. In P. Domeradzki, W. Tyburski (eds.), Zrozumieć samotność. Studium interdyscyplinarne (pp. 329-349). Toruń: Wydawnictwo UMK.

Earley, L. \& Cushway, D. (2002). Parentified Child. Clinical Child Psychology and Psychiatry, 7(2), 163-178.

Eiseberg, N. (1992). The Caring Child. Cambridge, MA: Harvard University Press. Grzegorzewska, I. (2016). Parentyfikacja w rodzinach z problemem alkoholowym. Alcoholism and Drug Addiction, 29, 27-38.

Hooper L. M. (2008). The Application of Attachment Theory and Family Systems Theory To The Phenomena of Parentification. The Family Journal: Counseling and Therapy for Couples and Families, 15, 217-233.

Izdebska, J. (2004). Dziecko osamotnione w rodzinie. Białystok: Wydawnictwo Trans Humana.

Jurkovic, G. J. (1997). Lost Childhoods: The Plight Of The Parentified Child. New York: Brunner/Mazel Publishers.

Jurkovic, G. J., Thirkield, A. \& Morrell, R. (2001). Parentification of adult children of divorce: A multidimensional analysis. Journal of Youth and Adolescence, 30, $245-257$.

Lalak, D. (2010). Podejście biograficzne (biograficzność) w naukach o wychowaniu. Trzy perspektywy dyskursu. In S. Palka (red.), Podstawy metodologii badań w pedagogice (pp. 257-280). Gdańsk: Gdańskie Wydawnictwo Psychologiczne.

Łopatkowa, M. (1983). Samotność dziecka. Warszawa: Wydawnictwa Szkolne i Pedagogiczne.

Minuchin, S. (1974). Families and Family Therapy. Boston, MA: Harvard Press i London: Tavistock. 
Riemann, G. \& Schütze, F. (1992). Trajektoria jako podstawowa koncepcja teoretyczna w analizach cierpienia i bezładnych procesów życiowych. Kultura i Społeczeństwo, 34(2), 89-111.

Schier, K. (2012). „Gdy dziecko staje się rodzicem” - odwrócona troska, czyli zjawisko parentyfikacji w rodzinie. In B. Tryjarska (ed.), Bliskość w rodzinie. Więzi $w$ dzieciństwie a zaburzenia $w$ dorosłości (pp. 63-80). Warszawa: Wydawnictwo Naukowe Scholar.

Schier, K. (2015). Dorosłe dzieci. Psychologiczna problematyka odwrócenia ról w rodzinie. Warszawa: Wydawnictwo Naukowe Scholar.

Schütze, F. (1983). Biographieforschung und narratives Interview. Neue Praxis, (3), 283-293.

Sławecki, B. (2012). Znaczenie paradygmatów w badaniach jakościowych. In D. Jelmieniak (ed.), Badania jakościowe. Podejście i teorie, vol. 1 (pp. 57-87). Warszawa: Wydawnictwo Naukowe PWN.

Urbaniak-Zając, D. \& Kos, E. (2013). Badania jakościowe w pedagogice. Warszawa: Wydawnictwo Naukowe PWN. 
